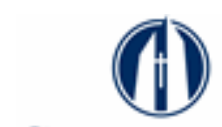

GeOrge Fox

UNIVERSITY

Digital Commons @ George Fox University

Faculty Publications - Grad School of Clinical

Psychology

Graduate School of Clinical Psychology

2018

Spiritual Formation in the Graduate School of Clinical Psychology at George Fox University

Rodger K. Bufford

Nancy S. Thurston

Kathleen Gathercoal

Marie-Christine Goodworth

Lynn H. Holt

Follow this and additional works at: https://digitalcommons.georgefox.edu/gscp_fac

Part of the Christianity Commons, and the Psychology Commons 


\title{
Spiritual Formation in the Graduate School of Clinical Psychology at George Fox University
}

\author{
Rodger K. Bufford \\ Nancy S. Thurston \\ Kathleen A. Gathercoal \\ Marie-Christine Goodworth \\ Lynn H. Holt \\ George Fox University
}

\begin{abstract}
At its inception, the training model in the Graduate School of Clinical Psychology (GSCP) at George Fox University was informed by the approach inaugurated at Fuller Theological Seminary School of Psychology in the 1960s. In the original model, training in Christian religion/spirituality and theology accompanied training in professional psychology. In the interim, our culture, psychological knowledge, perceived psychological needs, and training programs have changed greatly. Here we report changes in religion/spirituality $(R / S)$ training and integration over the last two decades. We describe our current spiritual formation structure and process, and program evaluation efforts. Over the past several years the GSCP has shifted from relying mainly on a cognitive approach involving Bible and theology courses (theoretical-conceptual integration) toward a more personal-experiential approach that includes team teaching of the theology and religion courses, an individualized spiritual direction experience spread over two years, and more intentional integration of $R / S$ and spiritual formation components throughout the program. We anticipate this may be an ongoing area for further development in coming years as we seek to meet the needs of a changing student body with greater R/S diversity and largely postmodern worldviews.
\end{abstract}

\footnotetext{
Corresponding author:

Rodger K. Bufford, Graduate School of Clinical Psychology, George Fox University, 414 N Meridian St. V-104, Newberg, OR 97।32, USA.

Email: rbufford@georgefox.edu
} 


\section{Keywords}

spiritual formation, graduate education, health service psychology, R/S integration

Relationships matter. They matter both in Christian teaching and practice and in psychological theory and practice. However, relationships are often strained, fractured, or shattered. We live in a world too often characterized by hostility rather than grace. Many of our current cultural models are aggressive, strident, even hostile. As followers of Christ, we are called to a different path.

For Christians, relationship is central to the person of God as well as to Christian community. At least in some Christian traditions, the Trinity of Father, Son, and Holy Spirit are portrayed as coequals in power and partnership, each mirroring the others and in ongoing communication with them. Christians also understand God as entering into relationship with us, accepting us and meeting us where and as we are.

Relationship is also a central concept in Health Service Psychology (HSP). Respect is emphasized in the ethical principles of psychologists. ${ }^{1}$ Relationship is seen as the most important element in psychotherapy, ${ }^{2}$ as well as an underlying principle of client-centered therapy. ${ }^{3}$ Relationship is identified as one of the core competencies of $\mathrm{HSP}^{4}$

Historically, the psychology profession has treated the private lives of psychologists as largely irrelevant to their professional work. For example, the professional ethics code states,

This Ethics Code applies only to psychologists' activities that are part of their scientific, educational, or professional roles as psychologists.... This Ethics Code applies ... across a variety of contexts, such as in person, postal, telephone, internet, and other electronic transmissions. These activities shall be distinguished from the

1. American Psychological Association, "Ethical Principles of Psychologists and Code of Conduct," American Psychologist (2010): 1060-1073.

2. Rita B. Ardito and Daniella Rabelino, "Therapeutic Alliance and Outcome of Psychotherapy: Historical Excursus, Measurements, and Prospects for Research," Frontiers in Psychology 2, 270 (2011); P. Cuijpers et al., "Psychotherapy for Depression in Adults: A Meta-analysis of Comparative Outcome Studies," Journal of Consulting \& Clinical Psychology 76 (2008): 909-922; M. S. Karver et al., "Meta-analysis of Therapeutic Relationship Variables in Youth and Family Therapy: The Evidence for Different Relationship Variables in the Child and Adolescent Treatment Outcome Literature," Clinical Psychology Review 26 (2006): 50-65; John C. Norcross, Psychotherapy Relationships That Work: Evidence-based Responsiveness (2nd ed.) (New York: Oxford University Press, 2011).

3. Carl Rogers, Client-Centered Therapy (Cambridge: Riverside Press, 1951).

4. Nadya A. Fouad et al., "Competency Benchmarks: A Model for Understanding and Measuring Competence in Professional Psychology across Training Levels," Training and Education in Professional Psychology 3, no. 4 Suppl. (2009). 
purely private conduct of psychologists, which is not within the purview of the Ethics Code. $^{5}$

Increasingly, however, character and fitness are emphasized. Private conduct is considered relevant to professional work for psychologists and other professionals: "you bring yourself into the room." Finger-printing and background checks have become routine in recent years. In Oregon, where we reside, for example, this standard was introduced for psychologists several years ago. ${ }^{6}$ In 2015 , ORS 676.150 was passed, creating a duty for psychologists and other professionals to report criminal acts and "unprofessional conduct" of other professionals. Thus we see a growing concern about the personal lives of psychologists.

Moon and Benner were among the first to address the interface of contemporary psychology with spiritual direction and soul care ${ }^{7}$. Spiritual formation during graduate training in health service psychology was extensively addressed in a special issue of the Journal of Psychology and Christianity in $2013 .^{8}$ The spiritual formation aspects of the GSCP at that time were described by McMinn et al. ${ }^{9}$ Here we provide a current view of the spiritual formation process in the GSCP as it has continued to be transformed over the past several years. In the following material, we describe (1) the program context, structure, and model of spiritual formation, (2) the teaching curriculum, (3) extra-curricular aspects of spiritual formation, (4) conceptual and empirical perspectives, and (5) offer our conclusion.

5. American Psychological Association, "Ethical Principles of Psychologists and Code of Conduct."

6. Oregon Revised Statutes: Oregon Board of Psychology, Statutes Pertaining to the Practice of Psychology (Salem: BPE), accessed February 22, 2018, http://www.oregon.gov/obpe/Pages/laws_ rules.aspx.

7. Gary W. Moon and David G. Benner, Spiritual Direction and the Care of Souls: A Guide to Christian Approaches and Practices (Downers Grove: Intervarsity Press, 2004).

8. Laura Fisk et al., "Spiritual Formation among Doctoral Students in Explicitly Christian Programs," Journal of Psychology and Christianity 32 (2013): 279-290; Kelly S. Flanagan et al., "Spiritual Formation Training in the Wheaton College PsyD Program: Nurturing the Growth of ServantOriented Practitioner-Scholars," Journal of Psychology and Christianity 32 (2013); Jason McMartin et al., "Spiritual Formation Training at Rosemead School of Psychology," Journal of Psychology and Christianity 32 (2013); Mark R. McMinn and B. Goetsch, "Spiritual Formation Training in Christian Psychology Doctoral Programs: Introduction to Special Issue," Journal of Psychology and Christianity 32 (2013); Mark McMinn et al., "Spiritual Formation Training in the George Fox University Graduate Department of Clinical Psychology," Journal of Psychology and Christianity 32 (2013); Jennifer S. Ripley et al., "Spiritual Formation Training at Regent University's Psychology Doctoral Program," Journal of Psychology and Christianity 32 (2013); Theresa Clement Tisdale, "Psychology and Spiritual Formation: The State of the Union," Journal of Spiritual Formation and Soul Care 7 (2014).

9. McMinn et al., "Spiritual Formation Training in the George Fox University Graduate Department of Clinical Psychology." 


\section{Program context, theological model, and structure of spiritual formation}

\section{Context}

As stated in the GFU mission, "George Fox University, a Christ-centered community, prepares students spiritually, academically, and professionally to think with clarity, act with integrity, and serve with passion." As an integral part of GFU, the GSCP shares the university mission. Further, the mission of the GSCP

is to provide excellent education and training for future health service psychologists who will provide outstanding professional services to their clients and agencies, and demonstrate special expertise when working with clients desiring a spiritual dimension, especially that characteristic of the Christian community. Consistent with the institutional mission of George Fox University, training is carried out within the framework of a Christian worldview and reflects the distinctive Quaker tradition of social service and advocacy for the rights and well-being of all persons, especially those whose opportunities are compromised by prejudice and injustice. This integration of faith, service, and clinical training is a central distinctive of the program. ${ }^{10}$

The following section explores the ways in which the GSCP engages in the "thriving and growing dialogue between psychology and spiritual formation." 11

The primary mission of the GSCP, as noted above, is to prepare health service psychologists who demonstrate Christian character and commitment and are prepared with the knowledge, skills, and attitudes to provide excellent psychological care that includes competence in addressing the religious and spiritual $(\mathrm{R} / \mathrm{S})$ concerns of their clients. Toward that end, the GSCP program has developed both curricular and ancillary activities designed to foster development of knowledge, skills, attitudes, and personal Christian character and commitment that promote these goals. Spiritual formation is one aspect of the process.

In the GSCP, spiritual formation is approached as a developmental process that is thoroughly intertwined with professional development in HSP. It begins with the backdrop of individual life experiences that each student brings to their training. Some students bring a history of personal trauma. Because we function holistically as integrated bio-psycho-social and spiritual beings, this trauma has an implicit spiritual component. Other students bring church experiences in which they were traumatized by a church leader or traumatized in another way that has an explicit spiritual component. Often this amalgam of trauma is less than fully processed as first-year students begin learning about theoretical models of spiritual formation while also learning models of psychopathology and psychotherapy. Slochower

10. Graduate School of Clinical Psychology, Graduate School of Clinical Psychology Handbook (Newberg: Graduate School of Clinical Psychology, 2017), 4.

11. Theresa Clement Tisdale, "Psychology and Spiritual Formation," 221. 
documented the role strain experienced by therapists who provide such holding environments for their patients, in which they must contain and bracket their own subjective distress while focusing outwardly on the patient's distress. ${ }^{12}$

Although spiritual direction is required by the GSCP, individual therapy is not. For logistic reasons, it was deemed a better fit to require spiritual direction as part of the spiritual formation curriculum, and use course credit to cover the cost. However, required individual therapy has been harder to implement. Students have expressed differences of opinions on this and it became a class project for a group of students in the Consultation, Evaluation, and Psychoeducation class. ${ }^{13}$ They found that $53 \%$ of the students in the program surveyed had engaged in their own psychotherapy. Of those who had not, $66 \%$ said therapy was too expensive. We will continue to consider whether or not to include individual therapy as part of the training process. For now, the spiritual formation aspect of the program is present and functioning.

A posture of humility is needed to receive either spiritual direction or individual therapy. Spiritual direction serves as an experiential process that can inform clinical training, and especially training to meet the $\mathrm{R} / \mathrm{S}$ concerns often encountered in the practice of HSP. Spiritual direction also can assist students with the challenging process of learning how to steward their experiences of vicarious trauma and engage in effective community and self-care.

In the psychological context, the development of self-knowledge as part of the clinical training and the experiential emphasis in spiritual formation lead to better interpersonal relationships. ${ }^{14}$ Meeting students where they are, allowing them to bring their whole persons, including their personal religion and spirituality into their professional roles as practicing psychologists, is congruent with professional guidelines and enhances their training. ${ }^{15}$

\section{Theological model}

Theologically, our approach to spiritual formation is broadly Christo-centric. It is significantly shaped by Quaker/Friends beliefs due to GFU's association with the Yearly Meeting of Friends. But it is also shaped by evangelical thinking within and apart from the Friends beliefs as well. The approach to individual spiritual formation is also significantly informed by patristic spiritual formation traditions.

12. J. A. Slochower, Holding and Psychoanalysis: A Relational Perspective (2nd ed.) (New York: Routledge, 2013).

13. Andrew Kenagy, Liliya Rudneva, Erin Besser, and Stephen Hancock, Individual Therapy or Spiritual Direction? (Unpublished manuscript, Graduate School of Clinical Psychology, George Fox University, Newberg, ORegon. 2013).

14. Rogers, Client-Centered Therapy.

15. American Psychological Association, "Ethical Principles of Psychologists and Code of Conduct." 


\section{Structure}

During the second year of training, our students begin their first clinical practicum experience. For some, it is their first substantial experience in working with psychotherapy clients. Many experience vicarious trauma as they face the suffering of fellow humans at such a visceral and intimate level, for sixteen hours per week. Messy and chaotic feelings and thoughts are stirred as clients' stories bring up the students' own incompletely resolved traumas. As faculty, we observe a tightening up of defenses in our second-year students coupled with growing strain and exhaustion from trying to manage the rigors of practicum and coursework. For years, our department has tried various classes and retreats in attempts to meet the spiritual and emotional needs of our second-year students.

The spiritual direction process is guided by the belief that spiritual development occurs in the company of a spiritual guide. The accompaniment relationship of spiritual direction is formed through deep listening and radical hospitality. Over the course of two years, this relationship provides an intentional time for students to share and wrestle with spiritual conversations and seek soul care. Many of our students had a Christian upbringing of some kind and many retain aspects of their heritage. The process of graduate education is intense, and the human experiences of suffering and trauma found in the therapeutic setting often lead to new and profound questions that invite greater self-awareness and theological reflection. During these times students bump up against immature models of inherited spirituality and God-images that have been used to make meaning for the world and their lives. They often discover they had a language to talk about God but feel resistance when asked to describe their relationship or experience of $\mathrm{God}$. This rupture can produce a profound sense of being lost and disconnected, feelings of betrayal, anger, and despair, and/or perhaps a time of spiritual dryness or ambivalence. In addition, some students enter the program suffering from a spiritually destructive experience or other trauma that requires compassionate listening and time for loosening the grip of a harmful encounter and a destructive God-image. Exline describes this process as religious-spiritual struggle. ${ }^{16}$

Some report intense experiences of the power of love to heal and how their spiritual journey has been nourished in a church community. Others carry a sense of shame for not measuring up to their own or their church's expectations. Many feel the challenge in our contemporary culture of a growing recognition that there appears to be no single narrative or theory, either religious or secular, that can adequately give meaning to the complexity of human lives and culture. At times they and those around them question traditional sources of authority. Each student brings his or her unique background; so, in the spiritual direction relationship, we acknowledge the Director-God is intimately acquainted with each one. Spiritual directors listen for the God-images that emerge as an expression of students'

16. Julie J. Exline and Eric D. Rose, "Religious and Spiritual Struggles" Handbook of the psychology of religion and spirituality / edited by Raymond F. Paloutzian, Crystal L. Park. (pp. 315-330). (2013). 
ultimate concerns and students' values are respected and honored as a part of their authentic spiritual journey. Sometimes it appears as if one must unbelieve God (an immature image of God) for new vitality and healthy forms and language to emerge. This process of shedding immature God-images is what makes room for integrating new experience and meaning that is vital to mature adult spiritual development foundational for a spiritually reflective practitioner.

Fowler's stages of faith offer a lens through which to understand our students' developmental process in our program. ${ }^{17}$ As first-year students, they tend to evidence Fowler's "synthetic-conventional" stage that is characterized by acceptance of authority and conformity to social mores. By the middle of their second year, many of these students seem to move to the choppier waters of the "individuative-reflective" stage, which is characterized by cognitive restructuring in the midst of disillusionment and angst. As students move into their third year of study, many of them are knee deep in the internal work of individuation at both personal and professional levels. In the fourth year, students become engaged in mentoring second-year peers as a part of their supervision course. At this point, particularly after returning from internship interviews around the country, we often see signs of Fowler's "conjunctive" faith in our students. These students appear more centered and confident in knowing who they are; from that place of increasing differentiation they become more generative, seeking to provide the remaining students intellectual and relational gifts as they prepare to leave our community. These fourth-year students evidence an increased capacity to hold paradox, tolerate ambiguity, and reconcile their earlier stages of faith with a more satisfying, complex, and multidimensional understanding of their faith.

Spiritual formation is addressed in several ways in the GSCP. These include courses, and extra-curricular activities that include Christian life-style, community gatherings, and colloquia. Finally, personal spiritual formation and the development of integrative approaches to $\mathrm{R} / \mathrm{S}$ concerns in assessment and therapy are a common theme in individual conversations between faculty and students.

\section{Teaching curriculum}

At the inception of the GSCP we began teaching integration of psychology and Christian faith with largely a theoretical-conceptual approach in 1990. This approach was common among the integrative programs of the time. One of the challenges that gradually developed was the wide range of knowledge with which students enrolled; some had only very basic biblical knowledge, while others came with seminary degrees. As Gathercoal and Adams reported, although elements of integration were woven through the curriculum, at that time GSCP students studied psychology and theology in separate classes and with different professors. ${ }^{17}$ Students complained that theology classes were "a waste of time." To some degree faculty echoed this view, though perhaps for different

17. James W. Fowler, Stages of Faith: The Psychology of Human Development and the Quest for Meaning (New York: Harper and Row, 1981). 
reasons. Further, the challenging of faith that often occurred in the theology courses as students encountered diverse theological views tended to leave many students floundering rather than enthusiastically engaged in developing something better. ${ }^{18}$ Both the work of Sorenson which occurred about this time and our own experience led us to implement changes. ${ }^{19}$

Reflection at this time led to a shift in curriculum from a mostly cognitive emphasis on Bible and theology toward an increased focus on individualized experiential R/S formation. A two-semester spiritual formation class was developed and the change was well received. ${ }^{20}$ The current four-semester spiritual formation curriculum (see below) was subsequently initiated in response to student feedback about the initial courses. Currently several students each year choose to continue their spiritual formation experience for a third year although it is not required by the GSCP. In the conclusion of his summary of a decade of research on learning integration, Sorenson stated, "What is crucial to students' integration is a dynamic, ongoing process that a mentor is modeling before the students' eyes ... it is something that's still in formation." ${ }^{21}$ Sorenson's notion of spiritual formation is a key concept underlying the curriculum of the GSCP. While much of the curriculum addresses the knowledge, attitudes, and skills of health service psychology, the integrative components described in the following section address the religious/spiritual formation of their attitudes and persons (or selves) and the ways spiritual formation is interwoven with training in the practice of HSP. In addition to the specific courses described here, the interrelationship of psychology and Christian R/S is a thread woven throughout the curriculum of the GSCP; each syllabus now documents the ways in which this topic is addressed.

\section{PSYD 6/6-Spiritual formation I}

The first spiritual formation course is provided during the first semester of the students' graduate studies in the Psy.D. program. The emphasis has historically been on developing a sustainable spiritual practice for graduate school and learning about spiritual practices and disciplines from contemporary and historical spirituality as they relate to the students' personal and professional lives. The course has been

18. Kathleen G. Gathercoal and Wayne A. Adams, "The Graduate School of Clinical Psychology at George Fox University: Learning to be a Practitioner-Scholar within a Christian Community," Journal of Psychology and Christianity 23, no. 4 (2004).

19. Ibid.

20. Randall Lehmann Sorenson, "Doctoral Students' Integration of Psychology and Christianity: Perspectives via Attachment Theory and Multidimensional Scaling," Journal for the Scientific Study of Religion 36 (1997); Randall Lehmann Sorenson, "Janusian Integration," Journal of Psychology and Theology 25 (1997); Rebecca Staton et al., "How Students Learn Integration: Replication of the Sorenson (1997a) Model," Journal of Psychology and Theology 26 (1998).

21. Kathleen G. Gathercoal, "Spiritual Direction and Psychotherapy: Exploring Right Relationships with God and the Self" (Newberg: Paper presented at the Friends Association for Higher Education, 2014). 
taught by either a clinical psychology faculty member, a spiritual formation faculty member, or a combination. Writing a spiritual autobiography, developing an experiential practice, experimenting with journaling, and researching in depth on an aspect of spiritual formation are all required as part of this foundational course in spiritual formation.

\section{PSYD 57 I-Integrative approaches to psychology and psychotherapy}

This course addresses the worldview foundations that underlie psychology and theology and explores the intersection of psychological and $\mathrm{R} / \mathrm{S}$ perspectives. These include views of about what exists, how things work, how we are able to know things, notions of good and evil, and what it means to be human (these are ontology, cosmology, epistemology, philosophical ethics, and philosophical anthropology). Both disciplines are influenced significantly by the answers to these questions. ${ }^{22}$

Next we explore the ways psychology and theology relate to each other and explore ways to resolve apparent discrepancies between them such as the emphasis on natural causes in psychology and on choice/responsibility in Christian theology. Third, the history of integration of psychology and Christian faith is examined. Fourth, the ways Christian beliefs might inform the practice of psychology are examined.

We conclude with reflection on where psychology may best fit into the contemporary church. Throughout this course a therapy model is articulated that parallels cognitive-behavioral psychotherapy, but adds emphases on development, relationship, and story. A recent change in this course that echoes the increasing emphasis on the personal/experiential side of integration was the addition of an individual integration interview as a class assignment that furthers personal/experiential integration and allows for individual conversations with each student about her or his personal and R/S background, and how that interacted with the student's experiences in the course.

\section{PSYD 6/7-620-Spiritual formation}

In the third through sixth semesters students are provided a guided spiritual development experience involving spiritual reading, reflection, journaling, monthly peer gatherings, and three meetings with a spiritual director each semester. The objective of these courses is to foster continued spiritual formation by intentionally creating a supportive structure and space for students to engage in self-discovery and group formation with a community of peers. The courses are largely experiential, inviting self-care and encouraging personal spiritual practices of reading, meditation, prayer, and other ways of creating space for God with the support of a spiritual director.

22. Randall Lehmann Sorenson et al., "National Collaborative Research on How Students Learn Integration," Journal of Psychology and Christianity 23 (2004): 355-365. 
Spiritual direction addresses two concerns. First, it puts the spotlight on personalexperiential R/S development and integration; it thus concentrates on a neglected domain of R/S and integrative development. Second, it allows us to accommodate for the wide variety of backgrounds that students bring. Spiritual direction supports students as they reflect on and reexamine their own spiritual and religious identity and experience in light of new learning about themselves and others amidst their development as professional psychologists. Students enter with various degrees of knowledge about God (cognitive) and unique experiences of God. As they encounter clients in their suffering, deep, honest, and sometimes troubling questions naturally surface. Sometimes a student's personal knowledge and experience can be in tension with his or her faith tradition and communities. A safe and confidential place is necessary as new understandings of self and God-images shift and mature.

In one-on-one conversations with students, trained spiritual directors create a safe space in order to host honest questions and contemplative reflection so students learn to listen for God in their own lives and hearts, often in places previously assumed to be separate from God's domain. The process of spiritual direction takes place within the broader framework of God's gracious presence, recognizing God as the real Director. The presence of a spiritual director helps students articulate and savor their experience of God.

The GSCP provides a list of approved spiritual directors that have training, practical experience, and qualifications that meet the criteria for these courses. The class fee covers the cost of the required twelve meetings. Students are free to choose anyone from the list. Our hope is that students will journey with the same spiritual director in both their second and third years of the program.

\section{PSYD 572-Bible survey for psychologists}

The Bible survey for psychologists course is team taught by a core faculty member of the GSCP and a Bible scholar in the Religion department at GFU. This course investigates the Bible, providing an overview that emphasizes unity within thematic and structural elements and offers a basis for continued theological and integrative studies. Interpretation is explored, with attention given to meaningful application of central themes in psychological practice.

The course explores major themes and content of the Bible, including its sociological and historical context. Students learn to articulate their own personal understanding of the Bible, demonstrating both self-awareness and awareness of the ways their view of the Bible shapes their worldview assumptions and has implications for their future work. Students also gain experience and confidence in discussing the Bible and how it pertains to the work of Christians in professional psychology as they encounter R/S diversity among their peers and clients.

Students achieve several competencies pertaining to diversity in this course. The course continues to evolve over time in an effort to meet student needs. Students take this required course during the fall term of their second year of doctoral study. At the 
same time, they are engaging in their first practicum experience and are, at times, vicariously traumatized by close proximity with the suffering of their clients, for whom they come to deeply care. Students discover the divergence of each other's understanding of the Bible, at times resulting in veiled or open conflict. A biblical basis for civility in discourse is planned for discussion the next time this course is offered. Texts such as Santa Biblia by Gonzalez are also being offered to broaden students' awareness of diversity in understanding the Bible.

\section{PSYD 574-Spiritual and religious diversity in professional health service psychology}

This course also is team taught by a core faculty member of the GSCP and a Bible scholar in the Religion department at GFU. The class is based on a learning model that seeks to develop awareness, knowledge, and skills, and an attitude of grace and humility. It fulfills the diversity competency in the curriculum. ${ }^{23}$ Class activities include a visit to a Buddhist Temple and a Mosque, as well as lectures, discussions, and experiential project presentations. It provides an overview of the major religions of the world.

Course objectives include introduction to the development and teachings of major contemporary non-Christian religious faiths, including Buddhism, Confucianism, Hinduism, Indigenous Religions, Islam, Jainism, Judaism, Rastafarianism, Shintoism, Sikhism, and Taoism. Students also gain an appreciation for spiritual and religious diversity and understand its relevance to clinical practice, as well as better understand how to do psychotherapy effectively with patients from a variety of religious backgrounds. Additionally, students gain empathy and respect for clients from diverse religious backgrounds, as well as recognize that these various world religions exist within historical, theological, psychological, anthropological, and sociological dimensions. Elements shaping multicultural understandings of God, humans, the world, and the purpose/goal of life are explored with special attention given to how professional psychologists can be sensitive to and effective in dealing with clients who hold various religious views, concerns, and practices.

\section{PSYD 578-Christian history and theology survey for psychologists}

This team-taught course is taken by third-year students. Theological literature tends to be written in the language of particular church traditions. As a result, many of our students find that studying theology includes learning new theological vocabulary. The readings, discussions, and reflection papers in the course are designed to familiarize graduate students with orthodox Christian theology, provide an overview of church history, and allow students to address how these are related to their

23. Rodger K. Bufford, "Philosophical Foundations for Clinical Supervision within a Christian Worldview," Journal of Psychology and Christianity 26 (2007). 
therapeutic work. Professional competencies relevant to the course include cultural diversity, professional values of self-awareness and lifelong learning, and interprofessional communication and relationships. ${ }^{24}$ To these ends, the course asks students to read papers, present case studies that conceptualize the presence of theological concepts in therapy, and discuss how these concepts impact them personally as therapists.

\section{PSYD 579-Spiritual and religious issues in health service psychology}

The final class in the integration curriculum is a capstone course intended to have students reflect on their spiritual and professional journeys and interact with themes related to being a health service psychologist and a person of faith. Topics addressed include suffering, humility, compassion, and forgiveness. Most of these age-old principles can find roots in Christian spirituality. Integrating them into professional and personal practice is one of the aims of the course, especially as they have highly significant positive mental and physical health outcomes. Students discuss these topics with each other. Openness to diversity and differences in worldview is both modeled and fostered. Throughout the semester, students engage in the spiritual discipline of examen on their clinical practicum days. In this discipline, they journal and reflect on where they found God and where they missed God during their clinical encounters to further their understanding of the interplay between their vocation and their spirituality.

Students also develop a final project that is reflective of their integration of their spiritual and professional journeys. They share this project at the end of their last semester of coursework, before they embark on their predoctoral internship.

\section{Extra-curricular spiritual formation}

Apart from the formal curriculum, spiritual formation occurs in several other areas of graduate experience as well. Among these are personal Christian lifestyle, GSCP community gatherings, and a colloquium series.

\section{Christian lifestyle}

Historically, the GSCP has used a lifestyle statement that emphasized behavioral proscriptions. Due to increasing unease with the legalistic tone, we have recently shifted to a lifestyle statement that is both more focused on aspirations than proscriptions and attends more to the heart than to behavior.

24. American Psychological Association Office of Program Consultation and Accreditation, Standards of Accreditation in Health Service Psychology (Washington, DC: American Psychological Association, 2015). 
In the Graduate School of Clinical Psychology, we attempt to explore together what it means to be followers of Jesus, both individually and collectively. While the university's Statement of Faith provides a summary of what we believe, Christians have always held that beliefs (orthodoxy) have implications for behavior (orthopraxy), and so we strive to encourage one another toward a lifestyle that demonstrates love, joy, peace, patience, kindness, goodness, faithfulness, gentleness, and self-control (Galatians $5: 22)^{25}$

When Jesus was asked to identify the most important commandment of Scripture, he replied by saying that we are to love God with our whole being, and to love our neighbors as we love ourselves. ${ }^{26}$ This is our aspiration, our telos, as a community and as individuals. As such, we make every effort to create an environment where students, faculty, and staff consider the welfare of the community and the needs of the world in addition to personal aspirations. This calls all of us toward personal awareness, cultural humility, intellectual honesty, and interpersonal compassion as we are being formed spiritually.

\section{Community gathering}

The entire GSCP community gathers monthly for food and fellowship. Students, faculty, and staff convene, share a meal, and reflect on various themes together. This is a time for informal relationships across cohorts and between students and faculty designed to deepen relationships outside of academic expectations. Each year a group of five students who represent each of the cohorts commits to serve on the community-gathering committee; they dedicate their time and energy to plan and organize this time. Dr. McMinn, Director of Integration for the GSCP, serves as a faculty advisor for this group. The committee plans the food, decides on the discussion themes, or invites a guest speaker. This monthly hour-and-a-half experience is a priority for our program and is generally very well attended.

\section{Colloquium series}

In addition to the integration courses in the GSCP, each year the entire department attends an Integration Colloquium. The Chair of Integration selects speakers to present all-day or half-day seminars on various topics relating to the integration of Christian faith and psychological practice. Integration Colloquium topics have included Mindfulness and Christian Integration by Dr. Erica Tan, Relational Psychoanalysis and Christian Faith: A Heuristic Dialogue by Dr. Marie Hoffman, Spiritual Formation and Psychotherapy by Dr. Barret McRay and Integration and Ekklesia by

25. Tbid.

26. Gal. 5:22, New American Standard Version. 
Dr. Michael Vogel. Each Integration Colloquium contains competency-based learning objectives for attendees.

\section{Conceptual and empirical perspectives}

Historically, the literature on relating psychology to Christian beliefs has emphasized three domains: theoretical-conceptual, research-empirical, and applied applied-clinical integration. Theoretical-conceptual integration deals with identifying similarities and differences in the ways human functioning is understood in psychology and theology. Research-empirical integration explores the ways in which psychological research sheds light on theology and psychological theory, providing confirmation or casting doubt. Applied-clinical integration revolves around the ways human problems are conceptualized, the interventions that are embraced and avoided in addressing them, and goals toward which clinical work might aim. More recently, Bufford conceptualized integration as a four-legged stool. These legs include theoretical-conceptual, research-empirical, applied-clinical, and personal-experiential integration. Adding personal-experiential integration reflected a conceptual shift. Personal-experiential integration had been largely neglected aside from the seminal work of Sorenson and his colleagues. ${ }^{27}$ However, it is the personalexperiential aspect of training that we now emphasize most strongly in the GSCP.

McMinn et al. provided an earlier description of spiritual formation training in the GSCP. ${ }^{28}$ They noted that spiritual formation among psychology trainees may promote spiritual growth, foster self-care, and reduce bias toward others. At that time GSCP students first completed a two-hour course focused on spiritual formation with an experiential emphasis. Next they completed a course involving two one-day community retreats. Third, they completed a service project. Above we describe spiritual formation components of the GSCP program as they have developed since.

Since McMinn's writing, the GSCP has continued the shift from mostly emphasizing theological knowledge and theoretical-conceptual integration toward a greater emphasis on spiritual formation and personal-experiential integration. There likely are several reasons for the historical neglect of personal-experiential integration. First, this neglect somewhat parallels common theological emphases and approaches to spiritual development in the USA that emphasize right thinking or orthodoxy, and right doing or orthopraxy. But the personal-experiential side of theology and practice have been largely neglected (Figure 1).

Neglect of personal-experiential formation is true to such a degree that most of us lack even a common word for this domain. Knight calls this orthopathy, an unfamiliar word except as it applies to an offshoot of medical practice. Orthopathy

27. Matt. 22:37, New American Standard Version.

28. Sorenson, "Doctoral Students' Integration of Psychology and Christianity"; Sorenson, "Janusian Integration"; Sorenson et al., "National Collaborative Research on How Students Learn Integration." 


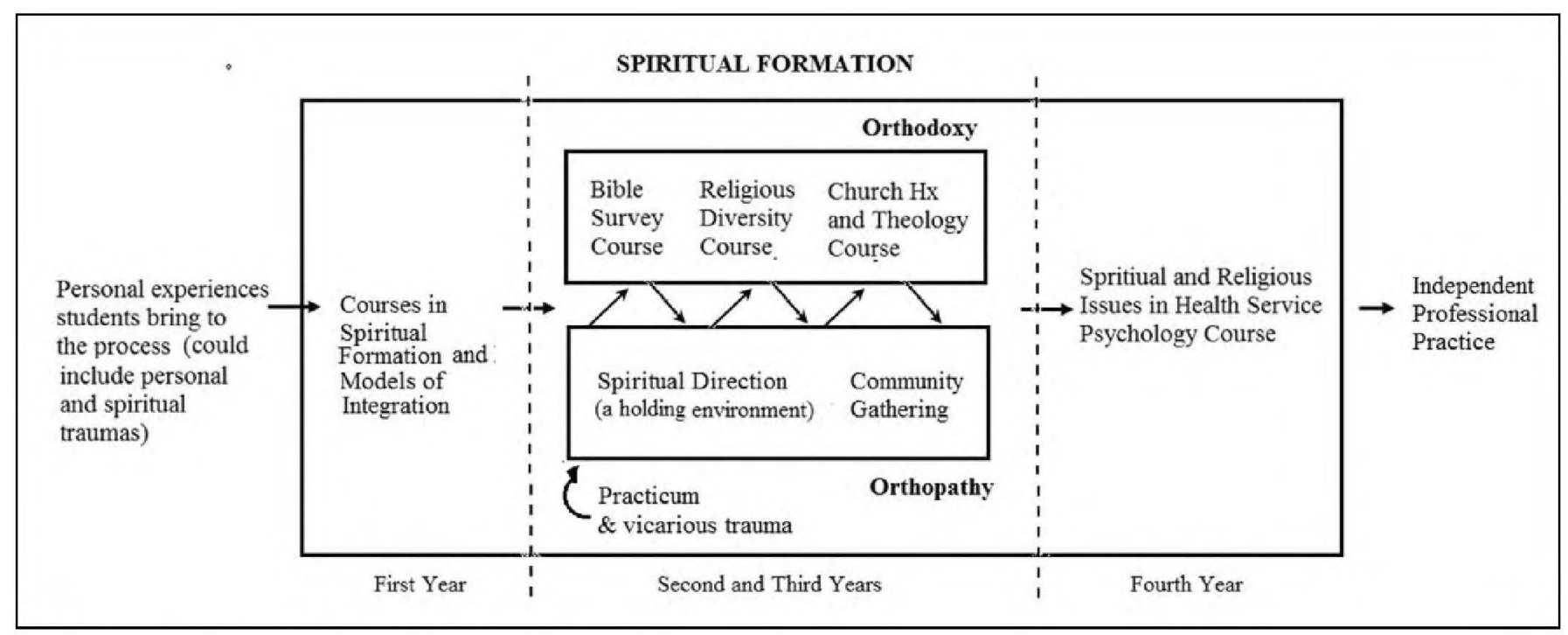

Figure I. Developmental process of spiritual formation in the GSCP. 
describes the affective-motivational, and to some degree the relational, aspects of Christian living. Knight noted,

While Wesley scholars do not have a common definition of "orthopathy," they use it to point to either of two features of Wesley's theology. The first has to do with how we know God, and the second with the transformation of the heart that comes from knowing God. ${ }^{29}$

In the spiritual formation components described above, knowledge-or theology-remains a component, but the personal-experiential component-or orthopathy-is emphasized.

Second, the history of our program played a role in the initial emphasis on mostly theoretical-conceptual knowledge in the religion and theology domains. During the era when the program was developed (1990), parallel training in psychology and in religion/theology was a common practice among then-existing integrative programs. This approach was inaugurated by the Fuller Theological Seminary School of Psychology in the $1960 \mathrm{~s}$. In part, our program was designed to be similar to these other programs. Another factor, more apparent in retrospect that at the outset, is that the GFU religion faculty involved in the religious and theological training hoped to use the courses developed for our program as the core for a Master's degree in religion/ theology; thus the courses were developed as much to meet the needs of preparation for advanced religious and theological studies as to meet the needs of those whose career path was to provide mental health services that were informed by Christian religious and theological understanding. In the interim the different needs for these two paths have become more clear.

Third, the personal-experiential side of integration involves aspects of ourselves and our experiences that are difficult to put into words. Lacking the needed words, yet needing at some level to address this domain, our conversations constantly tend to shift back into words and the theoretical-conceptual domain.

Fourth, faculty and students tend to operate from different worldviews, modern and postmodern, respectively, by virtue of our differences in ages and developmental histories. In a recent conversation with a perceptive and mature student, it was proposed that one of the challenges that I (Bufford) face in teaching our introductory integration course is that I tend to operate from a modern worldview, while students often come from a postmodern worldview. As a result, all too often we may misunderstand each other due to subtle differences in the way we use language and perceive events - even shared events.

Finally, program self-evaluation has played a role in this transition. Selfevaluation is an ongoing aspect of the GSCP program as specified by The APA

29. McMinn et al., "Spiritual Formation Training in the George Fox University Graduate Department of Clinical Psychology." 
Commission on Accreditation and Program Evaluation. ${ }^{30}$ Thus a full discussion of program evaluation is beyond the scope of this report. We hope to provide that separately. Here we briefly identify several program evaluation steps which together have shaped the spiritual formation transformation of our program over the past several years. Ongoing self-study was the foundation for many of the program changes described above. Self-study has been complemented by several program evaluation and research studies. ${ }^{31}$ Heyne reported that as students progress through their training they undergo a shift from a God-locus of control to an internal-locus of control, ${ }^{32}$ while other studies raised further questions suggesting the possibility that students move away from living faith during graduate study. These findings were seen as a somewhat troubling development and gave further impetus to the personalexperiential emphasis in the GSCP curriculum. Ongoing studies seek to further investigate R/S development during graduate training. These explore the interaction among emotional intelligence, burnout, and faith development, ${ }^{33}$ examine how selfcompassion and psychological flexibility interact with personal trauma, ${ }^{34}$ and investigate the development of cultural humility among graduate HSP students. ${ }^{35}$

In summary, as a result of ongoing program evaluation and dissertation studies over the course of the past several years, the GSCP training program has gradually shifted away from primarily emphasizing the development of biblical and theological knowledge—orthodoxy—to accompany psychological training toward a more individualized experiential spiritual formation process. Several factors gave impetus to this movement. Among these were student feedback, program evaluations conducted as part of accreditation self-studies, and program evaluation and research

30. Henry H. Knight, "Wesley's Orthopathy: Wesley and the Methodists," Catalyst, accessed February 20, 2018, http://www.catalystresources.org/consider-wesley-21/.

31. American Psychological Association Office of Program Consultation and Accreditation, Standards of Accreditation in Health Service Psychology (Washington, DC: American Psychological Association, 2015).

32. Rodger K. Bufford and Kathleen A. Gathercoal, Modeling, Mentoring, and the Learning of Psychology (Integration) (Valley Forge, PA: Paper presented at the annual meeting of the Christian Association for Psychological studies, 2007); Erica L. Eisele, Faith Experiences among Doctoral Psychology Students (Unpublished doctoral dissertation, George Fox University, 2012); Kathleen A. Gathercoal, Spiritual Direction and Psychotherapy: Exploring Right Relationships with God and the Self (Newberg: Paper presented at the Friends Association for Higher Education, 2014); Kathleen A. Gathercoal and Wayne V. Adams, "The Graduate School of Clinical Psychology at George Fox University: Learning to be a Practitioner-scholar within a Christian Community," Journal of Psychology and Christianity 23, no. 4 (2004): 3203-24; Laura K. Heyne, God Control among Doctoral Psychology Students: A Compressed Longitudinal Design (Unpublished doctoral dissertation, George Fox University, 2014).

33. Garret Blankenship, Emotional Intelligence's Relationship to Spirituality, Developmental Faith, and Burnout in Doctoral Clinical Psychology Students (Newberg: Unpublished doctoral dissertation, 2018).

34. Heather Harris, Graduate Student Professional Quality of Life (Newberg: Unpublished doctoral dissertation, 2018).

35. Tricha Weeks, email message to author, February 22, 2018. 
conducted by students working under faculty supervision. The current approach to learning about the relationships of psychology and Christian faith and learning to address $\mathrm{R} / \mathrm{S}$ concerns in practice retains elements of theoretical-conceptual and research-empirical integration, but more strongly emphasizes applied-clinical integration, and emphasizes personal-experiential integration as a primary focus. We believe this emphasis is more closely aligned with spiritual formation. It also enables us to better meet our students' perceived needs and better prepares them to bring their persons, including their personal religion and spirituality, into their professional roles as practicing psychologists in a way that is congruent with professional guidelines. This change in emphasis in spiritual formation also more closely aligns with the relational dimension of psychotherapy.

\section{Conclusion}

Orthodoxy, orthopraxy, and orthopathy; each matter. Ideas underlie and undergird our work as psychologists. What we do matters. In the GSCP we have been brought over the past several years toward a recognition that orthopathy has been neglected in our training and practice. While it is the world in which we often dwell as individuals, it is difficult for us to put into words our passions, motivations, and internal experiences. To some extent these are also marginalized in the academy-or at least they have been. We tend to compartmentalize - or worse. Still, as we seek to prepare students to enter into the lives of their clients and seek to foster wholeness and healthy thriving in them, we find the need to increase the degree to which we attend to this aspect of human functioning in our training. As a faculty, we see a need to continue to explore ways to more fully bring ourselves into the training process and more fully engage our students at a personal-experiential level as well. We believe this path will foster healthy personal and corporate functioning, and better train our students to enter into the dark places of their clients' lives with a healing presence. We also need to constantly remind ourselves that this is a developmental process that includes R/S struggle and that development and struggle are messy and chaotic processes. 